\title{
MEDIA SOSIAL DAN KEKERASAN BERBASIS GENDER ONLINE SELAMA PANDEMI COVID-19
}

\author{
Nur Hayati \\ Program Studi Sosiologi, FHISIP, Universitas Terbuka \\ e-mail: nurhayati1@ecampus.ut.ac.id
}

\begin{tabular}{l}
\hline \multicolumn{1}{c}{ Article Info } \\
\hline Keyword: \\
Pandemic \\
Online gender-based \\
violence \\
Social media \\
Deviant behavior
\end{tabular}

\section{Article Info}

\section{Kata Kunci:}

Pandemi

Kekerasan berbasis gender online

Media sosial

Perilaku menyimpang

\begin{abstract}
Online gender-based violence is a major threat to society. Especially now, the use of the internet for social media is increasingly widespread and rapid. Moreover, during the pandemic that hit Indonesia, where most of the community's activities were carried out at home, it was possible that online gender-based violence (KBGO) would occur on social media. Based on Komnas Perempuan data in CATAHU 2021, it was noted that in 2020 there was a spike in KBGO cases, which was around 940, which in 2019 recorded 241 cases. With this case in mind, the author conducted research on social media and online genderbased violence during the COVID-19 pandemic. The purpose of this article is to make us more aware that KBGO continues to stalk the public. This study uses a literature study research method by collecting, recording, and processing data from various reading materials such as books, journals, and internet sources. The research results show that KBGO is most commonly found on social media platforms Facebook, Instagram, and WhatsApp. The forms of KBGO found were varied, such as online sexual harassment with verbal violence, online grooming, and threats by distributing immoral photos or videos. One of the disadvantages of social media is that it makes deviant behavior or KBGO perpetrators. Social media, which should be used as a medium for building relationships with other people, has instead become a place where KBGO takes place. Therefore, social media is considered not to have a safe space for women. To protect $\mathrm{KBGO}$ on social media, a legal protection is needed that is serious about handling KBGO cases and can help women get out of the trap of KBGO cases.
\end{abstract}

\section{Abstrak}

Kekerasan berbasis gender online yang merupakan ancaman besar bagi masyarakat. Terutama sekarang ini, penggunaan internet untuk media sosial semakin marak dan pesat. Apalagi selama pandemi melanda Indonesia yang aktivitas masyarakatnya banyak dilakukan di rumah, tidak menutup kemungkinan semakin besar pula terjadinya kekerasan berbasis gender online (KBGO) dalam media sosial. Berdasarkan data Komnas Perempuan dalam CATAHU 2021 tercatat bahwa pada 2020 kasus KBGO mengalami lonjakan, yaitu sekitar 940 yang pada 2019 tercatat 241 kasus. Dengan adanya kasus tersebut, untuk itulah penulis melakukan penelitian tentang media sosial dan kekerasan berbasis gender online selama pandemi covid-19. Tujuan dari artikel ini adalah agar kita semakin sadar bahwa KBGO terus mengintai masyarakat. Penelitian ini menggunakan metode penelitian studi literatur dengan mengumpulkan, mencatat, dan mengolah data dari berbagai bahan bacaan seperti buku, jurnal, dan sumber internet. 
Hasil penelitan menunjukkan bahwa KBGO paling banyak ditemukan pada platform media sosial Facebook, Instagram, dan WhatsApp. Bentuk KBGO yang ditemukan ini beragam, seperti pelecehan seksual online dengan kekerasan verbal, online grooming, dan ancaman dengan menyebarkan foto atau video asusila. Keburukan dari media sosial salah satunya menjadikan perilaku menyimpang atau pelaku KBGO. Media sosial yang seharusnya dapat dijadikan sebagi media membangun relasi dengan orang lain, malah menjadi tempat terjadinya KBGO. Oleh karenanya, media sosial dianggap tidak memiliki ruang aman bagi perempuan. Untuk mendapatkan perlindungan atas KBGO di media sosial, dibutuhkan payung hukum yang serius menangani kasus KBGO dan dapat membantu perempuan keluar dari jerat kasus KBGO.

\section{Pendahuluan}

Hari demi hari bahkan tahun, kekerasan berbasis gender marak terjadi. Kekerasan berbasis gender ini dapat terjadi kepada siapa saja, baik perempuan maupun laki-laki. Namun, karena kita tinggal di lingkungan dengan budaya patriarki yang masih sangat kental, kerentanan terhadap kekerasan ini lebih mengarah terjadi pada perempuan (Stephanie, 2020). Pelakunya pun siapa saja, baik keluarga, teman dekat, atau masyarakat umum lainnya yang bahkan kita tidak mengenalnya. Isu tentang kekerasan berbasis gender merupakan isu penting yang terus bergulir hingga saat ini. Pada 2020, dalam catatatan Komnas Perempuan ada sekitar 1.300 kasus kekerasan berbasis gender yang dialami perempuan (Riski, 2021). Bahkan sekarang ini, dengan kemajuan teknologi internet dan semakin maraknya penggunaan media sosial, muncul kekerasan berbasis gender online (KBGO).

Kekerasan berbasis gender online (KBGO) adalah kekerasan yang difasilitasi teknologi terhadap seseorang didasarkan atas seks atau gender. Kekerasan berbasis gender online tidak dilakukan secara fisik, tetapi dengan berbagai cara seperti kekerasan secara verbal. SAFEnet (Asia Tenggara Freedom of Expression Network) merupakan organisasi yang memperjuangkan hak-hak digital di Asia Tenggara, melaporkan kepada Komnas Perempuan bahwa sepanjang 2017, setidaknya ada delapan bentuk kekerasan berbasis gender online, yaitu pendekatan untuk memperdaya (cyber grooming), pelecehan online (cyber harassment), peretasan (hacking), konten ilegal (illegal content), pelanggaran privasi (infringement of privacy), ancaman distribusi foto/video pribadi (malicious distribution), pencemaran nama baik (online defamation), dan rekrutmen online (online recruitment) (Kusuma, 2019).

Lalu, bagaimana isu kekerasan berbasis gender online ini pada masa pandemi Covid-19? Sekarang ini, bahkan sudah setahun pandemi Covid-19 melanda Indonesia. Hingga Juni 2021, certatat bahwa jumlah pasien Covid-19 di Indonesia mencapai mencapai 1.976.172 pasien positif. Berbagai usaha yang dilakukan pemerintah untuk mencegah penyebaran Covid-19. Salah satu upaya yang dilakukan pemerintah adalah memberlakukan pembatasan sosial berskala besar (PSBB) sesuai Peraturan Menteri Kesehatan No. 9 Tahun 2020. Tentunya, adanya PSBB ini sangat memengaruhi kehidupan dan aktivitas sosial masyarakat serta memengaruhi interaksi antarmasyarakat. Akibatnya, masyarakat banyak yang melakukan aktivitas dan menghabiskan waktunya di rumah serta mengurangi kegiatannya di luar rumah. Sekolah-sekolah melakukan pemberlakukan sekolah dari rumah (school from home) dan berbagai instansi memberlakukan bekerja dari rumah (work from home).

Aktivitas individu selama pandemi, seperti work from home atau school from home pun masih banyak dilakukan di rumah dengan memanfaatkan teknologi internet. Tidak hanya untuk bekerja atau belajar, mereka pun menggunakan internet untuk melakukan interaksi di media sosial, seperti Instagram, Facebook, Twitter, WhatsApp, dan Telegram. Instragram dan Facebook adalah media sosial yang memberikan fasilitas bagi pengguna untuk mengunggah foto mereka dan kemudian mengizinkan orang lain, termasuk orang asing mengomentari foto tersebut (Brown, 2018). Tidak 
hanya kedua media sosial tersebut, Twitter, WhatApp, dan Telegram pun memiliki fitur yang demikian.

Kemudahan mengakses internet nyatanya telah mengubah pola hubungan interpersonal yang menentukan norma dalam bertindak dan berinteraksi (Zhong, Kebbell, dan Webster dalam Jatmiko, 2020). Apalagi Indonesia termasuk negara yang pengguna media sosialnya mencapai 170 juta orang dengan intensitas menggunakan media sosial sampai 3 jam 14 menit per harinya, serta rentang umur penggunanya antara 18-34 tahun (Haryanto, 2021). Menurut Carr dan Hayes, media sosial merupakan media internet yang memudahkan penggunanya mengenalkan diri dan berinteraksi dengan orang lain, baik secara langsung maupun tidak langsung sehingga mendorong nilai dan persepsi dengan orang lain (Ikawati, 2018). Melalui media sosial inilah yang kemudian bisa jadi dapat memicu peluang semakin meningkatnya kekerasan berbasis gender online. KBGO merupakan ancaman yang besar bagi masyarakat. Terutama sekarang ini, penggunaan internet untuk media sosial semakin marak dan pesat, tidak menutup kemungkinan semakin besar pula terjadinya kekerasan berbasis gender online dalam media sosial. Hal ini dikuatkan dengan hasil penelitian dari Barak, Kowlaski dan Limber, Marwick dan Miller, Rodriguez-Darian dan Aguilera-Avila bahwa kemajuan teknologi telah memfasilitasi kekerasan berbasis gender online sehingga menjadi krusial yang membutuhkan perhatian khusus (Jatmiko, 2020).

Jika kita bisa melihat bahwa sebelum pandemi melanda Indonesia, kasus kekerasan berbasis gender online cukup rendah. Berdasarkan data Komnas Perempuan dalam Catatan Tahunan tercatat bahwa pada tahun 2018, korban kekerasan berbasis gender online tercatat mencapai 97 kasus. Pada tahun 2019 tercatat mencapai 241 kasus. Namun, dengan munculnya pandemi Covid-19, kekerasan berbasis gender online di Indonesia nyatanya malah melonjak, bahkan tahun 2020 naik sekitar 940 kasus. Ini menunjukkan bahwa kasus kekerasan berbasis gender online di Indonesia mengalami peningkatan yang sangat drastis. Hal ini sesuai dengan data dari Dokumen Rilis Pers SAFEnet 2021 bahwa angka kasus KBGO selama pandemi Covid-19 mengalami peningkatan, bahkan mencapai tiga kali lipat (LM Psikologi UGM, 2021) atau mengalami lonjakan kenaikan sekitar 300\% (Tanjung, 2021). Ini menunjukkan bahwa dengan adanya pandemi Covid-19 dan penggunaan internet untuk media sosial yang semakin meningkat, justru membuat peluang semakin banyaknya tindakan kekerasan, terutama tindakan kekerasan berbasis gender online.

Berdasarkan uraian tersebut, artikel ini dibuat untuk memperkaya kepustakaan yang membahas tentang kekerasan berbasis gender online di media sosial selama pandemi Covid-19. Apalagi kajian tentang kekerasan berbasis gender online ini merupakan isu yang menarik untuk diteliti, ditambah lagi dengan banyaknya kasus-kasus yang menimpa kerentanan perempuan di media sosial. Untuk itulah, artikel ini akan memfokuskan pada maraknya kekerasan berbasis gender online di media sosial selama pandemi Covid-19, penyimpangan sosial dalam media sosial, dan tidak adanya ruang aman bagi perempuan di media sosial.

\section{Metode Penelitian}

Metode penelitian yang digunakan dalam artikel ini adalah penelitian kualitatif deskriptif. Teknik pengumpulan datanya menggunakan teknik studi kepustakaan (study literature). Studi literatur adalah penelitian dengan menelaah kepustakaan yang diperlukan dalam penelitian secara tekun (Nazir, 2014:79). Dalam hal ini, penulis mengumpulkan, mencatat, dan mengolah berbagai infomasi dari berbagai bahan bahan bacaan, seperti jurnal, buku, dan sumber dari internet. Selain itu, penulis juga melakukan observasi dengan cermat dari berbagai media sosial dan mereviunya sehingga mendapatkan data yang berupa kata-kata secara detail.

\section{Pembahasan}

\section{Maraknya Kekerasan Berbasis Gender Online di Media Sosial selama Pandemi Covid-19}

Seiring dengan kemajuan teknologi dan pertumbuhan internet di Indonesia, jumlah pengguna media sosial pun semakin bertambah. Berdasarkan laporan We Are Social, bahwa per Januari 2021 
ada sekitar 170 juta penduduk Indonesia sebagai pengguna aktif media sosial dan mereka menghabiskan waktu berselancar di media sosial sekitar 3 jam 14 menit per harinya. Jenis media sosial pun beragam, seperti Youtube, Facebook, Instagram, Twitter, WhatsApp, dan Line. Sosial media tersebut merupakan jenis sosial media yang populer di Indonesia. Beberapa jenis media sosial tersebut memiliki fitur chat, unggah gambar, dan unggah video. Dengan adanya fitur-fitur tersebut, memudahkan terjadinya praktik kekerasan berbasis gender online. Berdasarkan hasil riset di Indonesia, media sosial Facebook, WhatsApp, dan Instagram menjadi platform yang paling banyak menjadi media kekerasan berbasis gender online (KBGO) (Mauliya, 2021).

Menurut Lidwina Inge Nurtjahyo, dosen Fakultas Hukum Universitas Indonesia, KBGO adalah tindakan menyerang tubuh, identitas gender, dan seksualitas seseorang dengan fasilitas teknologi digital (Nurtjahyo, 2021). Menurut Wiwik Afifah, Presidium Koalisi Perempuan Indonesia, kekerasan berbasis gender online adalah tindakan seseorang difasilitasi oleh teknologi, internet, telepon genggam, komputer, dan sebagainya yang disebabkan oleh perbedaan seks, gender, atau konstruksi sosial sehingga mengkibatkan munculnya kekerasan fisik, psikis, seksual, bahkan ekonomi. Menurutnya selama pandemi, kekerasan justru meningkat, terutama kekerasan secara online (Riski, 2021). Dengan demikian dapat dikatakan bahwa, KBGO adalah perbuatan berupa kekerasan terhadap tubuh, gender, dan konstruksi sosial seseorang yang difasilitasi oleh teknologi digital sehingga mengakibatkan dampak fisik, psikis, seksual, bahkan ekonomi.

Kekerasan berbasis gender online ini masih menjadi momok bagi masyarakat, terutama perempuan karena perempuanlah yang rentan mengalaminya. Apalagi di masa pandemi Covid-19 yang masyarakatnya banyak melakukan aktivitas secara daring, baik melakukan kerja dari rumah (work from home) dan belajar dari rumah (school from home), kasus KBGO-nya terus meningkat, di mana dalam praktik kekerasan berbasis gender online ini, perempuan menjadi target utamanya, meskipun memang tidak sedikit pula laki-laki yang menjadi korban KBGO. Menurut Association for Progressive Communications (APC), praktik KBGO meliputi tindakan kekerasan yang dilakukan, bersekongkol atau diperparah, sebagian atau seluruhnya dengan menggunakan teknologi informasi dan komunikasi (TIK), seperti ponsel, internet, platform media sosial, dan email (Maundu dalam Rahmawati, 2021).

Tidak hanya mengalami kekerasan dalam bentuk mengobjektivikasi tubuh dan penghinaan fisik (body shaming), perempuan juga mengalami berbagai komentar-komentar melecehkan, serangan seksual, penyebarluasan konten-konten seksual, baik berupa foto maupun video, maupun kekerasan verbal maupun grafis dalam media sosial. Bahkan berdasarkan survei kepada pekerja work from home yang dipublikasikan di media online cnnindoesia.com menunjukkan bahwa dari 315 pekerja, ada 86 orang yang mengalami kekerasan berbasis gender online (CNN Indonesia, 2020). Berikut contoh hasil tangkapan layar di media sosial tentang kekerasan berbasis gender online di media sosial selama pandemi Covid-19.
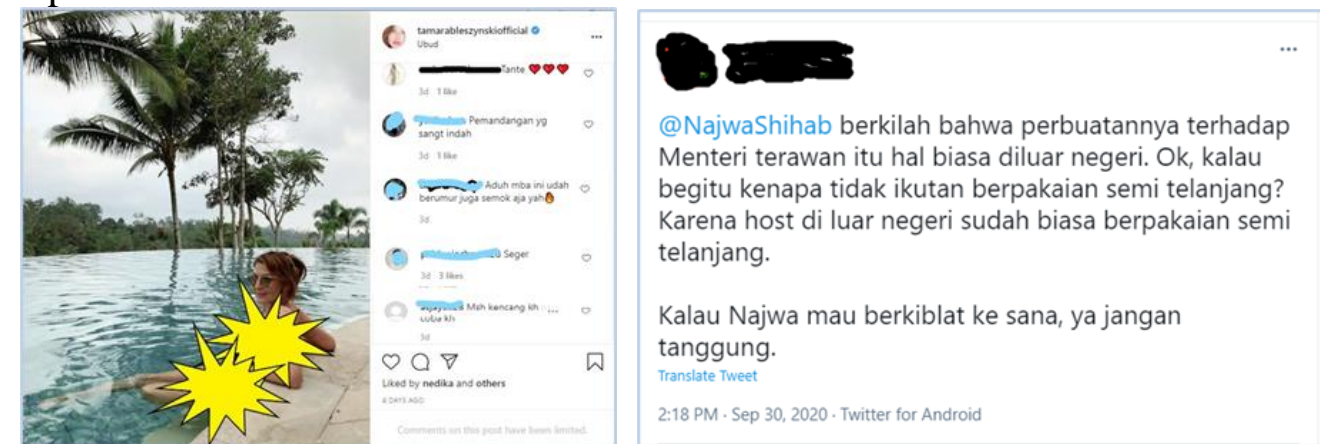

Jika melihat tangkapan layar tersebut, komentarnya termasuk contoh bentuk kekerasan berbasis gender online dalam bentuk pelecehan online (cyber harassment), terutama pelecehan seksual secara online (cyber sexual harassment). Pelecehan online (cyber harassment) adalah pengiriman teks untuk menyakiti atau menakuti atau mengancam atau menggangu (Komnas Perempuan, 2021). 
Gambar pertama (sebelah kiri) merupakan hasil tangkapan layar dari @ tamarableszynskiofficial pada 16 Juni 2021. Foto tersebut memperlihatkan unggahan foto seorang artis di Instagram, yaitu Tamara Bleszynski yang sedang berpose dengan baju renang di kolam renang. Sekilas tidak terlihat kekerasan berbasis gender online di sana, tetapi jika kita perhatikan, banyak bermunculan komentar-komentar dari para pengikutnya dalam menanggapi unggahan di Instagram-nya tersebut. Komentar-komentar tersebut mengarah pelecehan online, contohnya "Masih kenceng $k h$ bisa dicoba $k h$ " dan "Mbak ini sudah berumur tapi masih semok aja ya". Komentarkomentar semacam ini seakan-akan bentuk pujian terhadap orang yang ada di dalam foto tersebut, tetapi jika kita telaah kembali, komentar tersebut sebenarnya merupakan bentuk pelecehan seksual online yang menggambarkan perempuan sebagai objek seksual atau sexual harassment. Hal ini sesuai dengan pernyataan Komnas Perempuan bahwa pelecehan seksual adalah tindakan bernuansa seksual yang dilakukan dengan kontak fisik maupun nonfisik pada bagian tubuh seksual individu, seperti dengan cara bersiul, main mata, memberikan komentar bersifat seksual, memperlihatkan hal-hal yang berbau pornografi, sentuhan pada bagian tubuh tertentu, serta adanya isyarat seksual sehingga orang lain merasa tidak nyaman, merasa martabatnya direndahkan, tersinggung, dan bisa jadi sampai mengarah pada munculnya masalah kesehatan atau keselamatan (Ahsinin, 2015).

Selain pelecehan seksual, komentar yang muncul pun dapat dikatakan sebagai kekerasan verbal, di mana netizen melontarkan komenan seperti "Masih kenceng kh bisa dicoba kh". Tentunya komentar dalam bentuk kekerasan verbal semacam ini sangat menyakiti psikis dan merendahkan perempuan. Kekerasan verbal (verbal abuse) adalah perbuatan yang dilakukan seseorang untuk meremehkan atau memfitnah, merendahkan, dan menyakiti orang lain menggunakan bahasa atau kata-kata yang tidak baik (King dan Paramita dalam Wibowo, 2018). Sementara menurut Gunarsa, kekerasan verbal adalah perkataan atau ucapan yang menimbulkan rasa sakit pada psikis atau perasaan seseorang (Mamesah, Rompas, \& Katuuk dalam Mahmud, 2019).

Pada tangkapan layar kedua sebelah kanan memperlihatkan bahwa akun Twitter @NajwaShihab mendapat komentar dari netizen pada 30 September 2020. Netizen tersebut memberikan komentar bahwa "Najwa Shihab berkilah bahwa perbuatannya terhadap Menteri Terawan itu hal biasa di luar negeri. Ok, kalau begitu kenapa tidak ikutin berpakaian semi telanjang? Karena host di luar negeri sudah biasa berpakaian semi telanjang. Kalau Najwa mau berkiblat ke sana, ya jangan tanggung". Sedangkan dalam kasus ini, @ NajwaShihab tidak menanggapi komentar kebencian dan pelecehan seksual tersebut. Komentar yang berikan oleh netizen tersebut dapat dikatakan sebagai kekerasan berbasis gender online dalam bentuk pelecehan dari seseorang dengan melakukan ujaran kebencian dan unggahan di media sosial dengan target pada gender tertentu. Dalam hal ini, ujaran kebencian (hate speech) adalah komunikasi yang dilakukan seseorang maupun kelompok terhadap individu atau kelompok lainnya dalam bentuk hinaan, provokasi, maupun hasutan. Ujaran kebencian ini bisa mengarah ke berbagai aspek seperti warna kulit, ras, etnis, cacat, agama, kewarganegaraan, gender, orientasi seksual, dan sebagainya (Mawarti, 2018). Selain melakukan ujaran kebencian, netizen tersebut nyatanya juga melakukan kekerasan dalam bentuk pelecehan seksual, yaitu dengan melontarkan komentar agar Najwa Shihab untuk memakai baju semi telanjang.

Tidak hanya kekerasan berbasis gender online dalam bentuk sexual cyber harassment, bentuk KBGO online grooming juga marak terjadi selama pandemi ini. Bahkan dalam CATAHU 2021 tercatat bahwa ada 307 kasus online grooming. Kasus ini merupakan kasus tertinggi kedua setelah malicious distribution. Online grooming adalah perbuatan seseorang dengan mendekati seseorang atau korban yang kemudian membangun hubungan emosional di media sosial hingga akhirnya mendapat kepercayaan dari korban (Komnas Perempuan, 2021).

Salah satu kasus online grooming yang baru-baru ini terjadi, yaitu adanya pencabulan kepada gadis SMA oleh pelaku yang dikenalnya dari Facebook (Inge, 2021). Gadis SMA itu bernama DA (17), ia berkenalan dengan DN di media sosial Facebook. Kemudian karena merasa memiliki ketertarikan satu sama lain, mereka janjian untuk bertemu. Ketika bertemu inilah, pelaku melancarkan 
aksinya dengan melakukan pencabulan kepada DA di rumah pelaku. Dalam bayangan DA, sosok DN dianggap baik dan ramah, tetapi nyatanya tidak demikian. DN berubah menjadi sosok yang menakutkan. DA dipaksa menuruti nafsu bejat DN. Ia berusaha melawan, tetapi tidak berdaya. Bahkan DN kemudian juga memotret DA yang fotonya digunakan untuk mengancamnya. Berdasarkan kasus tersebut dapat dikatakan bahwa telah terjadi online grooming, di mana pelaku membangun koneksi terhadap korban yang kemudian memperoleh kepercayaan dengan bukti mereka saling bertemu atau kopi darat. Namun, kasus tersebut juga dapat ditambahkan sebagai kasus malicious distribution karena mengarah pada ancaman menyebarkan foto asusila DA apabila tidak menuruti kemauan DS.

Kasus kekerasan berbasis gender online lainnya yang banyak terjadi selama pandemi ini adalah bentuk ancaman penyebaran konten distribusi foto/video pribadi (malicious distribution). Malicious distribution adalah bentuk ancaman yang dilakukan seseorang dengan mengirimkan foto atau video pribadi, menghina menggunakan bantuan teknologi, komputer, maupun internet dengan membagikan informasi yang keliru, menyebarkan bahan hinaan terhadap seseorang atau korban di website, atau mengirimkan surel berisi fitnah untuk mencemarkan nama baik korban kepada seluruh teman ataupun keluarga korban (Komnas Perempuan, 2021). Sebagai contoh kasus malicious distribution yang belum lama ini viral di media sosial, yaitu ada pria berinisial YS memeras seorang artis. YS mengancam akan menyebarkan video asusila artis berinisial GL jika artis tersebut tidak memberikan uang kepadanya. YS mengambil video asusila GL dari media sosial, kemudian ia sunting, dipotong, dan mengirimkan video hasil editannya ke inbox media sosial pribadi milik GL. Berikut adalah kutipan dari isi inbox tersebut "Kalau Anda tidak ingin viral, saya membutuhkan uang, saya akan hapus video ini kalau sudah dibayar. Tapi kalau tidak akan saya sebarkan". Mendapat ancaman tersebut, GL kemudian melaporkan kejadian tersebut kepada pihak berwajib. Akibat tindakannya tersebut, YS dijerat Pasal 27 junto Pasal 45 UU tentang Informasi Transaksi Elektronik (ITE). Ancaman hukumannya, yaitu kurungan selama enam tahun penjara dan membayar denda satu miliar. Berdasarkan uraian tersebut dapat dikatakan bahwa kasus tersebut termasuk melicious distribution karena pelaku mengancam korban untuk menyebarkan video asusilanya jika tidak memberikan uang. Mengingat kembali bahwa berdasarkan CATAHU 2021, ada 370 kasus tindakan menyebarkan konten intim disertai ancaman pemerasan. Kasus ini bahkan menjadi kasus KBGO yang paling banyak dilaporkan (Komnas Perempuan, 2021).

Ketiga contoh tersebut merupakan beberapa contoh dari bentuk-bentuk kekerasan berbasis gender online di media sosial. Tidak hanya pelecehan online, online grooming, dan ancaman distribusi foto atau video pribadi, tetapi masih banyak kasus kekerasan berbasis gender online di media sosial selama pandemi ini, seperti memperdaya, peretasan, pelanggaran privasi, pencemaran nama baik, dan rekrutmen online. Memang, di media sosial, siapapun dapat dengan bebas memberikan komentar, mengirimkan pesan, atau mengeluarkan pendapatnya, baik yang sifatnya positif maupun negartif tanpa perlu khawatir karena mereka dapat membuat akun anonim. Namun, alangkah baiknya memanfaatkan media sosial dengan baik dan tepat, bukan malah melakukan kekerasan, terutama kekerasan berbasis gender online yang tentunya akan memengaruhi kondisi fisik dan psikis seseorang.

\section{Penyimpangan Sosial dalam Media Sosial}

Media sosial merupakan salah satu hasil kemajuan teknologi dan informasi. Adanya perkembangan teknologi informasi, internet sangat dibutuhkan oleh masyarakat untuk menunjang aktivitas mereka. Semakin pesatnya penggunaan internet inilah kemudian bermunculan berbagai platform-platform baru, seperti aplikasi media sosial (misalnya Facebook, Instagram, WhatApp, Twitter, Line, Telegram, dan Youtube). Media sosial ini merupakan situs atau aplikasi pertemanan atau jaringan sosial yang banyak digunakan masyarakat.

Media sosial memungkinankan penggunakan membuat akun dan berbagi isi atau konten yang mereka buat. Menurut Andreas Kaplan dan Michael Haenlein, media sosial adalah sekelompok 
aplikasi berbasis internet yang dibangun atas dasar ideologi dan teknologi Web 2.0, dan memungkinkan penciptaan dan pertukaran konten yang dibuat pengguna. (Ikawati, 2018). Sementara menurut Simmel; White, Boorman, dan Brieger, meluasnya penggunaan media sosial telah membentuk interaksi sosial baru dalam bentuk jejaring sosial, yaitu suatu struktur sosial dibentuk oleh seseorang atau kelompok yang dihubungkan satu atau lebih faktor saling ketergantungan, seperti persahabatan, persaudaraan, kepentingan bersama, perdagangan, ketidaksenangan, kepercayaan, kepercayaan diri, pengetahuan, dan prestise (Rosyidah, 2018).

Media sosial ini menawarkan berbagai fitur yang menarik dan berbagai kemudahan dalam penggunaanya. Media sosial ini menciptakan inovasi-inovasi baru sebagai bentuk sarana pertemanan atau interaksi dengan orang lain dengan lebih baik lagi. Tidak lagi hanya bisa chating, mengunggah foto atau video, tetapi fitur media sosial ini sudah bertambah dengan adanya fitur space (fitur baru di Twitter untuk melakukan interaksi dengan orang lain seperti layaknya podcast atau panggilan telepon) atau video call group.

Media sosial memiliki dua sisi sifat, yaitu baik dan buruk. Sisi baik media sosial antara lain dapat menambah teman, dapat berinteraksi dengan teman atau orang lain meskipun tidak saling mengenal, dapat digunakan sebagai media pembelajaran (misalnya menggunakan Youtube sebagai penyebaran materi pembelajaran), dan dapat memberikan informasi atau konten yang menarik. Namun di sisi lain, media sosial memberikan keburukan, misalnya saja timbulnya penyimpangan sosial atau perilaku menyimpang. Menurut M.Z. Lawang, perilaku menyimpang sebagai perilaku seseorang yang tidak selaras dengan nilai dan norma sosial yang ada dalam masyarakat. Sementara menurut James Vender Zender, perilaku seseorang yang oleh sebagai orang dianggap sebagai perbuatan yang tidak pantas dan di luar batas toleransi disebut sebagai perilaku menyimpang (Rosyidah, 2015). Dengan kata lain, penyimpangan (deviation) adalah perilaku tercela serta tidak sesuai nilai dan norma yang dilakukan oleh seseorang di masyarakat. Pelaku penyimpangan ini tidak hanya laki-laki, tetapi juga perempuan. Semakin banyaknya interaksi dengan media sosial, terutama selama pandemi ini mengakibatkan banyaknya perilaku menyimpang yang dilakukan di media sosial atau dunia maya.

Penyimpangan sosial yang muncul dalam media sosial ini sangat beragam, seperti perilaku kekerasan berbasis gender online yang di dalamnya terdapat melakukan pelecehan seksual, mengancam, grooming, mencemarkan nama baik, dan sebagainya. Perilaku kekerasan berbasis gender online ini merupakan bentuk penyimpangan sosial karena tidak sesuai nilai dan norma yang ada di masyarakat. Selain itu, dengan adanya penyimpangan sosial ini, interaksi sosial dalam media sosial akan menjadi rusak. Penyimpangan sosial yang berupa kekerasan berbasis gender online ini akan berdampak negatif bagi korbannya. Penyimpangan sosial yang dilakukan di media sosial sebagai bentuk kekerasan berbasis gender online adalah melakukan pelecehan seksual (cyber sexual harassment). Secara umum, cyber sexual harassment adalah segala perilaku yang dilakukan oleh pelaku secara sebelah pihak dan korban tidak mengharapkannya yang condong pada perkara seksual sehingga mengakibatkan rasa marah, benci, tersinggung, dan malu (Munir, 2019).

Pelecehan seksual ini tidak hanya sebatas melakukan kekerasan seksual kepada korbannya secara langsung, tetapi dilakukan secara tidak langsung. Beberapa tindakan perilaku menyimpang pelecehan seksual akibat intensnya penggunaan media sosial ini antara lain memberikan komentar atau pertanyaan tak senonoh baik seksual maupun eksplisit kepada seseorang, ajakan pornoaksi, dan menggunakan gambar tak senonoh untuk merendahkan perempuan. Sebagai contoh, kasus yang dialami Tamara Blezensky tersebut di atas. Di mana, ada komentar dari netizen "Masih kenceng kh bisa dicoba $k h$ ". Komentar semacam ini merupakan pelecehan seksual verbal di mana netizen melontarkan komentar yang tak senonoh yang tentunya melecehkan dan merendahkan perempuan. Karena belum adanya aturan yang tegas dalam menggunakan media sosial membuat pengguna media sosial ini dengan seenaknya melontarkan komentar atau pertanyaan yang melecehkan korban. Masih banyaknya komentar-komentar yang melecehkan perempuan ini sebagai membuktikan bahwa pengawasan dan kesadaran dalam penggunaan media sosial ini masih sangat rendah. 


\section{Tidak ada Ruang Aman bagi Korban Kekerasan Berbasis Gender Online}

Media sosial menjadi ruang bagi seseorang untuk melakukan interaksi dengan orang lain. Mereka membuat akun-akun pribadi untuk membangun jaringan dengan orang lain di dunia maya. Akun pribadi ini bisa berupa akun asli yang memperlihatkan jati diri dan mempresentasikan dirinya pada khalayak untuk mendapatkan teman atau relasi. Sementara maupun akun anonim digunakan untuk melakukan hal-hal sesuai dengan tujuan mereka, misalnya agar tidak dikenali oleh temannya ketika berkomentar di media sosial. Akun asli media sosial ini digunakan oleh seseorang untuk. Sementara media sosial selayaknya menjadi media atau sarana untuk memperluas jaringan pertemanan dan menambah informasi, tetapi kenyataannya tidak sedikit pula yang menggunakan media sosial sebagai tempat bahkan sarana melakukan penyimpangan sosial atau melakukan kekerasan berbasis gender online, seperti melakukan pelecehan seksual, grooming, mengancam, dan sebagainya.

Tren kekerasan berbasis gender online di media sosial menjadikan media sosial sebagai ruang baru dalam melakukan kekerasan terus meningkat, apalagi selama pandemi Covid-19 sekarang ini. Selain itu, banyaknya plarform media sosial yang mudah diretas dan semakin banyak bermunculan akun anonim juga meningkatkan KBGO. Berdasarkan data yang disajikan oleh DW, kasus KBGO dengan bentuk pelecehan terhadap perempuan ditemukan di beberapa platform media sosial dengan urutan dari paling banyak di media sosial Facebook yaitu sekitar 39\%, Instagram sekitar 23\%, Whatsapp sekitar 14\%, Snapchat sekitar 10\%, Twitter sekitar 9\%, dan TikTok sekitar 6\% (DW, 2020). Pelecehan yang dilakukan di media sosial ini sebenarnya sama saja seperti kekerasan secara langsung, bedanya hanya berpindah tempat di dunia maya saja. Selain itu, di media sosial atau dunia maya ini, pelaku pelecehan lebih bebas melakukan aksinya, ditambah lagi mereka semakin berani karena menggunakan akun anonim. ini menunjukkan bahwa dengan adanya tren kekerasan di media sosial, menjadikan korban terutama perempuan merasa sudah tidak memiliki ruang aman dan nyaman lagi.

Umumnya, setiap orang mempunyai hak memperoleh rasa aman dan nyaman dalam kehidupan sosial maupun bersosial media. Namun, dengan maraknya kekerasan berbasis gender online menjadikan mereka merasa sudah tidak aman lagi dalam bersosial media. Oleh karena itu yang mereka butuhkan adalah adanya perlindungan hak-hak perempuan dalam bersosial media tanpa gangguan kekerasan berbasis gender online dalam bentuk payung hukum. Salah satu upaya pemerintah untuk menghadapi dan menangani kasus kekerasan berbasis gender online (KBGO) ini adalah dengan membuat Rancangan Undang-Undang Penghapusan Kekerasan Seksual (RUU PKS). Akan tetapi sampai saat ini, RUU PKS ini masih menjadi pro kontra. Meskipun begitu, para aktivis mendorong untuk segera disahkannya RUU PKS tersebut.

Sembari menunggu RUU PKS yang masih belum disahkan sampai saat ini, sebenarnya Indonesia memiliki pasal-pasal yang mengatur hak asasi manusia. Pasal-pasal ini juga dapat dijadikan acuan untuk memenuhi rasa aman dan hak-hak perempuan untuk bebas berselancar di internet atau media sosial. Pasal-pasal tersebut antara lain Pasal 27 Ayat 1 serta Pasal 45 Ayat 1 tentang UndangUndang Informasi dan Teknologi Elektronik (ITE) yang sampai saat ini juga masih diperdebatkan karena dianggap pasal karet, Pasal 28E Ayat (3) UUD 1945 dan Pasal 19 Universal Declaration of Human Rights tentang kebebasan berkespresi, Pasal 28G Ayat (1) dan (2) UUD 1945 dan Pasal 17 Ayat (1) International Convenant on Civil and Political Rights tentang hak kemanan dan privacy, serta Pasal 29 UU Pornografi (Yayasansapa, 2020)

\section{Simpulan}

Kemajuan teknologi internet dan semakin maraknya penggunaan media sosial, muncullah kekerasan berbasis gender online (KBGO). Kekerasan jenis ini sama saja seperti kekerasan yang dilakukan secara langsung, bedanya kini kekerasan berbasis gender ini berpindah ke media sosial atau dunia maya. Apalagi selama pandemi ini, banyak bermunculan bentuk-bentuk kekerasan berbasis online di media sosial. Bentuk KBGO yang ditemukan ini beragam, seperti pelecehan seksual online dengan kekerasan verbal, online grooming, dan ancaman dengan menyebarkan foto atau video 
asusila. Keburukan dari media sosial salah satunya menjadikan perilaku menyimpang atau pelaku KBGO. Media sosial yang seharusnya dapat dijadikan sebagi media membangun relasi dengan orang lain, malah menjadi tempat terjadinya KBGO. Oleh karenanya, media sosial dianggap tidak memiliki ruang aman bagi perempuan. Untuk mendapatkan perlindungan atas KBGO di media sosial, dibutuhkan payung hukum yang jelas menangani kasus KBGO dan dapat membantu perempuan keluar dari jerat kasus KBGO. oleh karena itu, semoga RUU PKS segera disahkan.

Untuk mencegah terjadinya KBGO, pemerintah selaku stakeholder dapat melakukan sosialisasi kepada masyarakat secara berkala tentang KBGO serta upaya untuk menghindarinya dan mencegahnya. Selain itu, para pengguna media sosial sebaiknya melakukan tindakan preventif dari diri sendiri juga, misalnya dengan memfilter pertemanan jika ada yang meminta berteman di media sosial, tidak menanggapi komentar-komentar negatif, memblokir akun-akun pelaku kekerasan berbasis gender online, dan kejadian KBGO kepada pihak yang berwajib.

\section{Daftar Pustaka}

Ahsinin, Adzkar., Stiawati, Diyah., dkk (2015). BUKU SAKU: Mencegah dan Menangani Kekerasan Seksual terhdap Perempuan dan Anak di Lingkungan Pendidikan. PKWJ UI-MAGENTA LR\&A.

Brown. Jessica. (2018). Apa Saja Bukti Pengaruh Media Sosial Kehidupan Anda. Retrieved June 15, 2021, from https://www.bbc.com/indonesia/vert-fut-42679432.

CNN Indonesia. (2020). WFH Kala Pandemi Tingkatkan Pelecehan Seksual Online. Retrieved June $15, \quad 2021, \quad$ from https://www.cnnindonesia.com/gaya-hidup/20201209151208-284580017/wfh-kala-pandemi-tingkatkan-pelecehan-seksual-online

Divisi Redaksi. (2021). Peningkatan Kasus Kekerasan Berbasis Gender Secara Daring Selama Pandemi Menjadi Sorotan. Retrieved June 17, 2021, from https://www.bulaksumurugm.com/2021/03/08/peningkatan-kasus-kekerasan-berbasisgender-secara-daring-selama-pandemi-menjadi-sorotan/.

DW. (2020). Pelecehan Online terhadap Perempuan Mendorong Mereka Keluar dari Medsos. Retrieved June 15, 2021, from https://www.tempo.co/dw/3451/pelecehan-online-terhadapperempuan-mendorong-mereka-keluar-dari-medsos

Haryanto, Agus Tri. (2021). Pengguna Aktif Medsos RI 170 Juta, Bisa Main 3 Jam Sehari. Retrieved June 15, 2021, from https://inet.detik.com/cyberlife/d-5407834/pengguna-aktif-medsos-ri170-juta-bisa-main-3-jam-sehari.

Ikawati, Linda. (2018). Pengaruh Media Sosial terhadap Tindakan Kejahatan Remaja. SYARIATI: Jurnal Studi Al-Qur an dan Hukum, Vol. IV No.02 223-232. DOI: https://doi.org/10.32699/syariati.v4i02.1179

Inge, Nefri. (2021). Kenal di Facebook, Pelajar SMA di Palembang Jadi Korban Pencabulan. Retrieved June 18, 2021, from https://www.liputan6.com/regional/read/4472518/kenal-diFacebook-pelajar-sma-di-palembang-jadi-korban-pencabulan

Jatmiko, Mochamad Iqbal., Muh. Syukron, \&Yesi Mekarsari. (2020). Covid-19, Harassment and Social Media: A Study of Gender-Based Violence Facilitated by Technology During the Pandemic. The Journal of Society and Media, October 2020, Vol. 4(2) 319-347. DOI: 10.26740/jsm.v4n2.p319-347

Komnas Perempuan. (2021). Perempuan Dalam Himpitan Pandemi: Lonjakan Kekerasan Seksual, Kekerasan Siber, Perkawinan Anak, Dan Keterbatasan Penanganan Di Tengah Covid-19. Catahu 2021: Catatan Tahunan Tentang Kekerasan Terhadap Perempuan 2021, 1-3.

LM Psikologi UGM. (2021). Satu Tahun Pandemi: Meningkatnya Kekerasan Basis Gender Online. Retrieved June 18, 2021, from https://lm.psikologi.ugm.ac.id/2021/03/satu-tahun-pandemimeningkatnya-kekerasan-basis-gender-online/

Mahmud, Bonita. (2019). Kekerasan Verbal pada Anak. An Nisa' Vol. 12, No. 2, Desember 2019, 689-694 
Mauliya, Afina., Noor, Triana Rosalina. (2021). Cyber Safety in Response to Online Gender-Based Violence During The Covid-19 Pandemic. Jurnal Khitah: Kajian Islam, Budaya \& Humaniora Vol. 2 No. 1 Tahun 2021

Mawarti, Sri. (2018). Fenomena Hate Speech. TOLERANSI: Media Komunikasi umat Beragama Vol. 10, No. 1, Januari - Juni 2018 (83-95) DOI: http://dx.doi.org/10.24014/trs.v10i1.5722

Munir, Abdul., Krim, M., \& Harianto, Riki. (2019). Realitas Penyimpangan Sosial dalam Konteks Cyber Sexual Harassmentpada Jejaring Sosial Live Streaming Bigo Live. Sisi Lain Realita Vol. 4 No. 22019 (21-39) https://doi.org/10.25299/sisilainrealita.2019.vol4(2).4825

Nazir, Moh. (2014). Metode Penelitian. Jakarta: Ghalia Indonesia.

Nurtjahyo, Lidwina Inge. (2021). Kekerasan seksual di internet meningkat selama pandemi dan sasar anak muda: kenali bentuknya dan apa yang bisa dilakukan?. Retrieved June 17, 2021, from https://theconversation.com/kekerasan-seksual-di-internet-meningkat-selama-pandemi-dansasar-anak-muda-kenali-bentuknya-dan-apa-yang-bisa-dilakukan-152230.

Riski, Petrus. (2021). Kekerasan Berbasis Gender Daring Makin Marak. Retrieved June 17, 2021, from https://www.voaindonesia.com/a/kekerasan-gender-daring-marak-/5755134.html.

Rahmawati, Arifah., Udasmoro, Wening. (2021). Kekerasan di Masa Pandemi. Yogyakarta: Fakultas Ilmu Budaya, Universitas Gadjah Mada.

Rosyidah. (2015). Pengaruh Media Sosial Terhadap Penyimpangan Perilaku Pada Siswa. Millah Vol. XIV, No. 2, Februari 2015 (247-266) https://doi.org/10.20885/millah.volxiv.iss2.art3

Rosyidah, Feryna Nur., Nurdin, M. Fadhil. (2018). PERILAKU MENYIMPANG: Media Sosial Sebagai Ruang Baru Dalam Tindak Pelecehan Seksual Remaja. SOSIOGLOBAL : Jurnal Pemikiran dan Penelitian Sosiologi, Vol. 2, No.2, Juni 2018 (38-48)_

Kusuma, Ellen., Arum, Nenden Sekar. (2019). Memahami dan Menyikapi Kekerasan Berbasis Gender Online: Sebuah Panduan. Retrieved June 10, 2021, from https://id.safenet.or.id/wpcontent/uploads/2019/11/Panduan-KBGO-v2.pdf.

Stephanie, C. (2020). Kasus Kekerasan pada Perempuan via Internet Naik 3 Kali Lipat Selama Pandemi. Retrieved June 13, 2021, from https://tekno.kompas.com/read/2020/08/28/18000087/kasus-kekerasan-pada-perempuan-viainternet-naik-3-kali-lipat-selama-pandemi.

Tanjung, E. (2021). Kekerasan Berbasis Gender Meningkat 63 Persen di Masa Pandemi. Retrieved June 13, 2021, from https://www.suara.com/news/2021/02/11/052500/kekerasan-berbasisgender-meningkat-63-persen-di-masa-pandemi?page=all.

Wibowo, Fitriardi., Parancika, Rd. Bily. (2018). Kekerasan Verbal (Verbal Abuse) Di Era Digital sebagai Faktor Penghambat Pembentukan Karakter. PROSIDING SEMNAS KBSP V (pp. 172-178). Universitas Negeri Yogyakarta, Yogyakarta.

Yayasansapa. (2020). Media Sosial adalah Ruang Aman bagi Perempuan. Retrieved June 18, 2021 from http://yayasansapa.id/media-sosial-adakah-ruang-aman-bagi-perempuan/. 